\title{
On the Way to Empire?*
}

\begin{abstract}
The parallels between the crisis of the modern West and the fall of the Roman Republic in the 1st century BC are staggering: mass immigration, shrinking demography, decline of the family, erosion of the traditional religion, globalisation, social polarisation, a culture of bread and circuses, debt crisis, technocracy, asymmetrical wars, populism, etc. The present paper tries to summarise these analogies and reflects on the possibility of seing the West suffer similar events than those affecting the late Republic: civil unrest, rise of charismatic individuals, instauration of an authoritarian State.
\end{abstract}

Keywords: European Union, Western Civilisation, Ancient Rome, Roman Republic, Cultural Comparatism, Civil Unrest, Authoritarianism

\section{Introduction}

— ven if my assessment of the modern day and the arising consequences for Eu-

— rope seems rather bleak, I still think it is better to face reality than to indulge in comforting but potentially harmful delusions. I am convinced that the current, much-discussed crisis in Europe isn’t just a momentary “glitch” in history or an easily rectified wrong turn on the general path towards greater progress, freedom, democracy, prosperity and happiness, as the media so often claims. It is in fact the complete opposite. This crisis is the logical and inevitable outcome of the long-term development of Western society, rooted in numerous decisions and events, which can often be traced a long way back into the past.

* This lecture organised by Poznań Division of Polish Philosophical Society was given at the Department of Philosophy, Adam Mickiewicz University in Poznań, on October 21, 2019. Many thanks to Rachel Hansed for her translation of the text from German into English. 
Western Europe is staring into the abyss, and the utterly fraught sense of crisis along with the huge loss of confidence in politics is leaving its citizens fearing the worst. $88 \%$ of Belgian citizens are already convinced that our society is being pushed to its limits, and only $10 \%$ still trust the political elite in their country. Surveys from other Western European countries hardly offer a more positive assessment. ${ }^{1}$ However, as I tried to convey in my book "Le déclin - la crise de l’Union européenne et la chute de la République romaine”, it is evident to me that this current social crisis is by no means new or unique in the wider picture of human history. On the contrary, it possesses the same traits as numerous other transformational phases of various advanced cultures from the past. Having said this, the present situation most clearly mirrors the crisis of the Late Roman Republic in the first century BC. ${ }^{2}$

Unemployment, mass immigration, demographic decline, poverty, the disintegration of the family, materialism, secularisation, poor education, public debt, the democratic deficit, social costs, the reform bottleneck, crime, parallel societies, business relocation, terrorism, fundamentalism, speculation, plutocracies, loss of identity, asymmetrical wars and, to quote Cicero, ${ }^{3}$ the feeling of being "foreign" in one's own country - none of this is fundamentally "new”. In fact, it echoes the situation in the Late Roman Republic so closely that it is almost uncanny. In the following, we shall consider some of these points in greater detail to get a better sense of the full extent of the current crisis.

\section{The crisis of the Republic}

\subsection{Mass immigration}

Both in the cosmopolitan Late Roman Republic and in the blame culture of multicultural Europe in the 20th and 21st centuries, a move away from the ideal of an ethnically and culturally homogeneous state in favour of unrestricted tolerance and inflated diversity has encouraged increasing levels of mass immigration. This has diluted any defining culture, which inevitably leads to frustration, resentment

1 Source: 'Futuromètre’ from 2016, https://www.rtbf.be/info/societe/detail_futurometre-91-des-francophones-veulent-changer-de-systeme?id=9436297.

2 D. Engels, Le Déclin. La crise de l'Union européenne et la chute de la république romaine - analogies historiques, Paris 2013; cf. also the heavily expanded and revised German translation, published under the title: Auf dem Weg ins Imperium? Die Krise der Europäischen Union und der Untergang der römischen Republik. Historische Parallelen, Berlin - Munich 2014. The text presented here is a condensed and inevitably simplified overview over the general theses of this monograph.

${ }^{3}$ Cic., Acad. Post. 3.: We, who wandered around our city as if we were foreign guests, brought your writings home again, so that we could finally once again see who and where we are $[\ldots]$. 
and hostility towards foreigners. ${ }^{4}$ In the majority of Western European states, as much as a quarter of the population has a migrant background. ${ }^{5}$ Similarly, in the large Hellenistic cities and in Rome, topics such as foreign infiltration, deportation, citizen rights and human rights were also on the agenda, ${ }^{6}$ as Cicero demonstrates. In reference to the non-Italian residents of the city, and contrary to contemporary opinion, he believed that it was "fair that anyone who is not a citizen, does not have a citizen's rights [...]; but prohibiting foreigners from residing in a city, that is truly inhuman.” (Cic., off. 3.47). This uncontrolled demographic development also instilled fear, resentment and xenophobia in Rome, as was vividly described by Juvenal during the Roman Imperial Period:

(Iuv. 3.58-6) That race most acceptable now to our wealthy Romans, / That race I principally wish to flee, I'll swiftly reveal, / And without embarrassment. My friends, I can't stand / A Rome full of Greeks, yet few of the dregs are Greek! / For the Syrian Orontes has long since polluted the Tiber, / Bringing its language and customs, pipes and harp-strings, / And even their native timbrels are dragged along too, / And the girls forced to offer themselves in the Circus. / Go there, if your taste's a barbarous whore in a painted veil.

\subsection{Demographic decline}

The latent risk of poverty, career pressure and a view on pregnancy, children and parenting that is increasingly influenced by individualism and egoism are causing upheaval in the demographic behaviour of Europeans, ${ }^{7}$ just as it did for the Ro-

${ }^{4}$ On migration in the West, cf. T.J. Hatton, J.G. Williamson, The Age of Mass Migration, Oxford 1998; K. Bade, Europa in Bewegung. Migration vom späten 18. Jahrhundert bis zur Gegenwart, Munich 2000; S. Castles, M. Miller, The Age of Migration. International Population Movements in the Modern World, London 2003; C. Joppke, E. Morawska (eds), Toward Assimilation and Citizenship. Immigrants in Liberal Nation States, London 2003; J. Dupâquier, Y.-M. Laulan, Ces migrants qui changent la face de l'Europe, Paris 2004; T. Boeri, H. Brücker, Why are Europeans so Tough on Migrants?, "Economic Policy” 44, October 2005, pp. 629-703.

${ }^{5}$ Cf. the numbers given by the 'Statistisches Amt Bund/Länder (Bevölkerung nach Migrationsstatus regional)'. The proportion of children (up to 6 years) with a migration background was, in 2011: Frankfurt 75\%, Augsburg 61\%, Munich 58\%, Bremen 57\%, Duisburg 57\%, Nuremberg $51 \%$, Stuttgart 56\%, Dortmund 53\%, Darmstadt 52\%, Essen 50\%, Düsseldorf 50\%, Cologne 50\%, Berlin 48\%, Hamburg 48\%, Hanover 46\% etc.

${ }^{6}$ On migration in late-republican Antiquity cf. K.J. Beloch, Die Bevölkerung der griechischrömischen Welt, Leipzig 1886; citations including W. Suder, Census Populi. Bibliographie de la démographie de l'Antiquité romaine, Bonn 1988; T.G. Parkin, Demography and Roman Society, London 1992; L. Wierschowskli, Die historische Demographie - ein Schlüssel zur Geschichte?, "Klio“ 76/1994, pp. 355-380; M. Bellancourt-Valdher, J.-N. Corvisier, La Démographie historique antique, Arras 1999; G. Stangl, Antike Populationen in Zahlen. Überprüfungsmöglichkeiten von demographischen Zahlenangaben in antiken Texten, Frankfurt a. M. 2008.

${ }^{7}$ On the demographic decline in the West, cf. P.B. Baltes, J. Mittelstraß (eds), Zukunft des Alterns und gesellschaftliche Entwicklung, Berlin - New York, NY 1992; J. Siegmund, Bevölke- 
mans two thousand years ago. ${ }^{8}$ These factors are contributing to a huge decline in the population, which will deeply affect the welfare and social solidarity of future generations. Polybios described a situation which could easily be applied to modern-day Europe:

(Polyb. 36.17) In our own time the whole of Greece has been subject to a low birth-rate and a general decrease of the population, owing to which cities have become deserted and the land has ceased to yield fruit, although there have neither been continuous wars nor epidemics. [...] For as men had fallen into such a state of pretentiousness, avarice, and indolence that they did not wish to marry, or if they married to rear the children born to them, or at most as a rule but one or two of them, so as to leave these in affluence and bring them up to waste their substance, the evil rapidly and insensibly grew. For in cases where of one or two children the one was carried off by war and the other by sickness, it is evident that the houses must have been left unoccupied, and as in the case of swarms of bees, so by small degrees cities became resourceless and feeble.

\subsection{The crisis of the family}

Confusion between equality and gender identity, as well as the limitless individualism of modern consumer society, subvert the image of the family, both today and in the past. Both in the patriarchal society of Rome and in European society, which was formerly heavily influenced by the chivalrous ideal, records reveal an unprecedented divorce rate and the emergence of the so-called patchwork family. This is a tendency which clearly brings into question children's self-identification with their families along with the archetype of cultural solidarity and cohesion. ${ }^{9}$ In the Late Republic, ${ }^{10}$ there were reports of numerous scandals involving adultery and

rungsrückgang. Alterung und Technischer Fortschritt, Dresden 1993; H.-U. Klose (ed.), Altern hat Zukunft - Bevölkerungsentwicklung und dynamische Wirtschaft, Opladen 1993; J. Kopp, Geburtenentwicklung und Fertilitätsverhalten, Konstanz 2002; F.-X. Kaufmann, Schrumpfende Gesellschaft. Vom Bevölkerungsrückgang und seinen Folgen, Frankfurt a. M., 2005; C.D. Kernig, Und mehret euch? Deutschland und die Weltbevölkerung im 21. Jahrhundert, Bonn 2006.

${ }^{8}$ On the demographic decline in late-republican Antiquity, cf. A. Landry, Quelques aperçus concernant la dépopulation dans l'Antiquité gréco-romaine, "RH” 77/1935, pp. 1-33; P. Salmon, Population et dépopulation dans l'Empire Romain, Brussels 1974; J.-N. Corvisier, W. Suder, Polyanthropia-oliganthropia. Bibliographie de la démographie du monde grec, Paris 1996; E. Lo Cascio, Recruitment and the Size of the Roman Population from the Third to the First Century BCE, in: W. Scheidel (ed.), Debating Roman Demography, Leiden 2001, pp. 111-137.

${ }^{9}$ On the evolution of the family in the West, cf. J. Goody, The Development of the Family and Marriage in Europe, Cambridge, MA, 1983; K. Lüscher, F. Schultheis, M. Wehrspaun, Die 'postmoderne' Familie - familiale Strategien und Familienpolitik in einer Übergangszeit, Konstanz 1988; D.I. Kertzer, M. Barbagli, The History of the European Family. Family Life in the Long Nineteenth Century (1789-1913), Yale, CT 2002.

${ }^{10}$ On the evolution of the family in late-republican Antiquity, cf. E. Levy, Der Hergang der römischen Ehescheidung, Weimar 1925; M. Humbert, Le Remariage à Rome. Étude d'histoire juridique et sociale, Milan 1972; B. Rawson (ed.), The Family in Ancient Rome. New Per- 
divorce, a trend which continued into the Imperial period. ${ }^{11}$ For instance, Seneca bemoans the state of affairs despite the Imperial dynasty's efforts at moralisation:

(Sen., ben. 3.16) Is there any woman that blushes at divorce now that certain illustrious and noble ladies reckon their years, not by the number of consuls, but by the number of their husbands, and leave home in order to marry, and marry in order to be divorced? They shrank from this scandal as long as it was rare; now, since every gazette has a divorce case, they have learned to do what they used to hear so much about. Is there any shame at all for adultery now that matters have come to such a pass that no woman has any use for a husband except to inflame her paramour? Chastity is simply a proof of ugliness.

\subsection{Fear of being inundated by foreigners}

The imbalance between the steadily declining native population and the ever-increasing number of immigrants, who are cynically regarded as "import goods" to offset the weakening native population, gradually awakens fears among the wider population, which is already contending with the threat of unemployment and poverty. This group soon finds themselves the victims of a creeping ethnic repression and turns themselves into a minority in their own country. Today, these fears manifest themselves in almost weekly demonstrations led by concerned citizens. ${ }^{12}$ 2000 years ago, ${ }^{13}$ Emperor Augustus is said to have given the following speech to unmarried Romans:

spectives, London 1986; B. Rawson (ed.), Marriage, Divorce, and Children in Ancient Rome, Oxford 1991; I. Kajanto, On Divorce among the Common People of Rome, "REL" 47/1969, pp. 99-113; S. Treggiari, Roman Marriage. Iusti Coniuges from the Time of Cicero to the Time of Ulpian, Oxford 1991.

${ }^{11}$ Cf. also Gell. 4.3, who explains that the first case of divorce only happened 500 years after the foundation of the city: "It is on record that for nearly five hundred years after the founding of Rome there were no lawsuits and no warranties in connection with a wife's dowry in the city of Rome or in Latium, since of course nothing of that kind was called for, inasmuch as no marriages were annulled during that period."

${ }^{12}$ On the fear of strangers in the West, cf. T. Modood, P. Werbner, The Politics of Multiculturalism. Racism, Identity and Community in the New Europe, London 1997; C. Kleinert, Fremdenfeindlichkeit: Einstellungen junger Deutscher zu Migranten, Opladen 2004, E. Oeser, Die Angst vor dem Fremden. Die Wurzeln der Xenophobie, Darmstadt 2015.

${ }^{13}$ On the fear of strangers in late-republican Antiquity, cf. A.N. Sherwin-White, Racial Prejudice in Imperial Rome, London 1967; L. Cracco Ruggini, Pregiudizi razziali, ostilità politica e culturale, intolleranza religiosa nell'impero romano, “Athenaeum” 46/1968, pp. 139-152; H. Brandt, Panhellenismus, Partikularismus und Xenophobie. Fremde in griechischen Poleis der klassischen Zeit, "Eos” 80/1992, pp. 191-202; D. Engels, L'étendue de la cité est un objet que l'homme politique ne doit pas négliger. Les critiques de la mégapole dans l'Antiquité méditerranéenne, "Latomus” 72/2013, pp. 1055-1085; A. Coşkun, L. Raphael (eds), Fremd und rechtlos? Zugehörigkeitsrechte Fremder von der Antike bis zur Gegenwart. Ein Handbuch, Cologne - Weimar - Vienna 2014. 
(Cass. Dio 56.7-8) For surely it is not your delight in a solitary existence that leads you to live without wives, nor is there one of you who either eats alone or sleeps alone; no, what you want is to have full liberty for wantonness and licentiousness. [...]. For you see for yourselves how much more numerous you are than the married men, when you ought by this time to have provided us with as many children besides, or rather with several times your number. How otherwise can families continue? How can the State be preserved, if we neither marry nor have children? [...] And yet it is neither right nor creditable that our race should cease, and the name of Romans be blotted out with us, and the city be given over to foreigners - Greeks or even barbarians. Do we not free our slaves chiefly for the express purpose of making out of them as many citizens as possible? And do we not give our allies a share in the government in order that our numbers may increase? And do you, then, who are Romans from the beginning and claim as your ancestors the famous Marcii, the Fabii, the Quintii, the Valerii, and the Julii, do you desire that your families and names alike shall perish with you?

\subsection{Religion}

The spiritual aspects of cultural identity also appear to be in a seemingly unstoppable decline, particularly when it concerns traditional religions, whether that is Christianity today ${ }^{14}$ or Republican Polytheism in Roman times. ${ }^{15}$ Heavily criticised by both enlightened thinking and rationalist Hellenistic philosophy, the appeal of conventional forms of traditional religion is weakening to the extent that their time-honoured institutions are slowly dying out. Priesthoods become vacant, faith is something to be mocked, and sacred sites are left to decay. Meanwhile, atheism, agnosticism, esotericism and fundamentalism gain popularity - whether that is in the form of the "oriental cults" spread by migrants across the Roman Empire, such as Judaism or the Cult of Mithras, or through Islam and its parallel societies in modern-day Europe. Lucretius, for example, praised the philosophy of Epicurus for "throwing religion to the ground and trampling it, while victory raises us to heaven” (Lucr. 1.62-79). At the same time, Tacitus criticised Judaism, which had been present in Rome since the Late Republic, for its self-isolation and he warned of the dangers posed by the abundance of Jewish children:

${ }^{14}$ On the religious evolution of the West, cf. G. Vahanian, The Death of God: The Culture of Our Post-Christian Era, New York 1961; Th.J.J. Altizer, W. Hamilton, Radical Theology and the Death of God, Indianapolis 1966; H. Blamires, The Post Christian Mind: Exposing its Destructive Agenda, Vine 1999; Ph. Jenkins, God's Continent: Christianity, Islam and Europe's Religious Crisis, Oxford 2005; Ch. Taylor, A Secular Age, Harvard 2007.

${ }^{15}$ On the religious evolution of late-republican Antiquity, cf. G. Wissowa, Religion und Kultus der Römer, Munich 1912; J. Geffcken, Der Ausgang des griechisch-römischen Heidentums, Heidelberg 1920; K. Latte, Römische Religionsgeschichte, Munich 1960; R. Turcan, Religion romaine, Leiden 1988; J. Scheid, Religion et piété à Rome, Paris 2001; J. Rüpke, Die Religion der Römer, Munich 2006; D. Engels, Das römische Vorzeichenwesen, Stuttgart 2007. 
(Tac., Hist. 5.5.1-3) Whatever their origin, these rites are maintained by their antiquity: the other customs of the Jews are base and abominable, and owe their persistence to their depravity. For the worst rascals among other peoples, renouncing their ancestral religions, always kept sending tribute and contributions to Jerusalem, thereby increasing the wealth of the Jews; again, the Jews are extremely loyal toward one another, and always ready to show compassion, but toward every other people they feel only hate and enmity. They sit apart at meals, and they sleep apart, and although as a race, they are prone to lust, they abstain from intercourse with foreign women; yet among themselves nothing is unlawful. [...]Those who are converted to their ways follow the same practice, and the earliest lesson they receive is to despise the gods, to disown their country, and to regard their parents, children, and brothers as of little account. However, they take thought to increase their numbers $[\ldots]$.

\subsection{Globalisation}

Like ancient Romanisation, ${ }^{16}$ modern globalisation, ${ }^{17}$ along with the exaggerated idealisation of any form of "other" that is anchored in the cultural masochism of post-war European society, is eliminating a sense of solidarity with one's own cultural heritage. This is replaced by a cosmopolitan, humanist syncretism in which everything “foreign” appears superior to everything familiar, almost as a matter of principle. At the same time, and despite assurances to the contrary, this does not result in equal participation in the collectively produced wealth. Instead, there is an excessive concentration of possession in the major centres of power, which in turn increases resentment at the edges of society. Late Hellenistic philosophy, as reflected in Cicero, laid the foundations for the theory of a humanity united in globalised structures, which was explained by Aelius Aristides in the Imperial era in astonishingly pertinent words:

(Ael. Arist., Rom. (or. 14) [200] 11-12) Whatever each culture grows and manufactures cannot fail to be here at all times and in great profusion. Here merchant vessels arrive

${ }^{16}$ On globalisation in late-republican Antiquity, cf. vgl. E.S. Gruen, Culture and National Identity in Republican Rome, Ithaca, NY, 1992; J. David, La Romanisation de l'Italie, Paris 1994; R. Hingley, Globalizing Roman Culture. Unity, Diversity and Empire, London 2005; R.M. Geraghty, The Impact of Globalization in the Roman Empire, 200 BC-AD 100, "Journal of Economic History” 67/2007, pp. 1036-1061; M. Pitts, M.J. Versluys (eds), Globalisation and the Roman World. World History, Connectivity and Material Culture, Cambridge 2015.

${ }^{17}$ On the modern globalisation, cf. D. Cohen, La Mondialisation et ses ennemis, Paris 2004; J. Bhagwati, In Defense of Globalization, Oxford 2004; J. Brasseul, Un monde meilleur? Pour une autre approche de la mondialisation, Paris 2005; J. Fontanel, La Globalisation en »analyse«-Géoéconomie et stratégie des acteurs, Paris 2005; Blätter für deutsche und internationale Politik (ed.), Der Sound des Sachzwangs - Der Globalisierungs-Reader. With 30 contributions from Elmar Altvater, Samir Amin, Peter Bender, Noam Chomsky, Mike Davis, Erhard Eppler, Johan Galtung, Jürgen Habermas, Samuel P. Huntington, Naomi Klein, Birgit Mahnkopf, Peter Marcuse, Saskia Sassen et al., Bonn - Berlin 2006; B. Rehbein, H. Schwengel, Theorien der Globalisierung, Konstanz 2008. 
carrying these many commodities from every region in every season and even at every equinox, so that the city takes on the appearance of a sort of common market for the world. One can see cargoes from India and even, if you will, from southern Arabia in such numbers that one must conclude that the trees in those lands have been stripped bare, and if the inhabitants of those lands need anything, they must come here to beg for a share of what they have produced.

\subsection{Financial markets}

The increasing political and economic intertwining in the ancient Mediterranean region and in modern-day Europe not only encourages increasingly widespread speculation, but also a dangerous, mutual financial dependency, which means crises on the periphery could quickly lead to economic catastrophes in the centre. As in Late Republican Rome $^{18}$, the result of this in the $\mathrm{EU}^{19}$ is a necessity for ever greater centralisation and mutual alignment of the various federal states to reduce risk. At the same time, this advances the emergence of a powerful plutocracy, which increasingly gains control over the state and its institutions due to its influence. Cicero was clearly aware of this development as he stated in a speech:

(Cic., Man. 7.18f.) For we know that then, when many had lost large fortunes in Asia, all credit failed at Rome, from payments being hindered. For it is not possible for many men to lose their property and fortunes in one city, without drawing many along with them into the same vortex of disaster. But do you now preserve the republic from this misfortune; and believe me, (you yourselves see that it is the case,) this credit, and this state of the money-market which exists at Rome and in the forum, is bound up with, and is inseparable from, those fortunes which are invested in Asia. Those fortunes cannot fall without credit here being undermined by the same blow, and perishing along with them.

\subsection{World peace}

The increasing union of a cultural space that has mostly been brought about through peaceful means has led us to view our own society as an example for human civilisation in general. Internal and external opponents are all labelled terrorists, while our own government is considered the supreme guardian of world peace. International war is therefore replaced by the concept of defending "civilisation" against terror. Paradoxically, this relocation of war from the outside to within

${ }^{18}$ On the financial situation of late-republican Antiquity, cf. M. Rostovtzeff, Social and Economic History of the Roman Empire, Oxford 1926; M. Finley, The Ancient Economy, Berkeley, CA, 1973; N. Morley, Theories, Models and Concepts in Ancient History, London 2004.

${ }^{19}$ On the financial crisis situation of the West, cf. M. Otte, Der Crash kommt: Die neue Weltwirtschaftskrise und wie Sie sich darauf vorbereiten, Berlin 2006; S. Schmidt, Markt ohne Moral - Das Versagen der internationalen Finanzelite, Munich 2010; St. Jenks, Banken und Finanzkrisen, Lübeck 2012; D.M. Kotz, The Rise and Fall of Neoliberal Capitalism, Cambridge, MA, 2015. 
perpetuates a state of emergency and facilitates the erosion of the constitutional state due to the "no-alternative" necessity for police state security measures. This trend has been emerging all over Western Europe for some years now, ${ }^{20}$ and it is a phenomenon which also shaped the Late Republic and the Empire. ${ }^{21}$ In his first letter to his brother Quintus, Cicero developed a whole theory on the pacified Mediterranean, which then culminated in the following statement by Aelius Aristides during the Imperial era:

(Ael. Arist., Rom. (or. 14) (216) 69-71) War and even the fact that it once existed are subject to disbelieve, as even tales about it are considered as mere myths. And when, at some moment or another, there emerges some fighting at the frontier, which is quite natural, given the extent of this immense empire and the folly of the Dacians, the misfortunes of the Libyians or the misery of the people at the Red Sea, all incapable to enjoy the blessings of the present times, those wars disappear as quick as myths, and even tales about them. Such is the extent of the peace you are enjoying.

\subsection{Bread and circuses}

The gradual disappearance of a sense of the happy medium, originally firmly rooted in faith in the Roman mos maiorum as well as in European Christianity, facilitates the emergence of a purely materialistic pursuit for personal fulfilment, which in turn leads to egoistic careerism and increasing social polarisation. That is why in today's Western society, ${ }^{22}$ as in late-republican Antiquity, ${ }^{23}$ a consumer and social welfare

${ }^{20}$ On 'peace' in the West, cf. T. Nardin, The Ethics of War and Peace. Religious and Secular Perspectives, Princeton, NJ 1996; K. Koppe, Der vergessene Frieden. Friedensvorstellungen von der Antike bis zur Gegenwart, Opladen 2001; A. Hirsch, P. Delhom (eds), Denkwege des Friedens. Aporien und Perspektiven, Freiburg i. Br. - Munich 2007; F.-E. Boucher et al. (eds), La Paix. Esthétiques d'une éthique, Bern et al. 2007.

${ }^{21}$ On 'peace' in late-republican Antiquity, cf. L. Waddy, Pax romana and World Peace, New York 1950; S. Albert, Bellum iustum. Die Theorie des gerechten Krieges und ihre praktische Bedeutung für die auswärtigen Auseinandersetzungen Roms in republikanischer Zeit, Kallmünz 1980; M. Mantovani, Bellum iustum. Die Idee des gerechten Krieges in der römischen Kaiserzeit, Bern et al. 1990; C. Wendt, Sine Fine. Die römische Außenpolitik von der späten Republik bis in den frühen Prinzipat, Berlin 2008.

${ }^{22}$ On the society of 'bread and circuses' in the West, cf. J. Baudrillard, La Société de consommation, Paris 1970; G. Ritzer, The McDonaldization of Society, Thousand Oaks, CA, 1995; B.R. Barber, Consumed. How Markets Corrupt Children, Infantilize Adults, and Swallow Citizens Whole, New York, NY, 2008; H. Berghoff, U. Spiekermann (eds), Decoding Modern Consumer Societies, New York, NY, 2012; W. König, Geschichte der Konsumgesellschaft, Stuttgart 2000.

${ }^{23}$ On 'panem et circenses' in late-republican Antiquity, cf. D. van Berchem, Les distributions de blé et d'argent à la plèbe romaine sous l'Empire, Genève 1932; G. Rickman, The Corn Supply of Ancient Rome, Oxford 1980; P. Herz, Studien zur römischen Wirtschaftsgesetzgebung. Die Lebensmittelversorgung, Stuttgart 1988; P. Garnsey, Famine and Food Supply in the Graeco-Roman World. Response to Rise and Crisis, Cambridge, MA, 1988; E. Höbenreich, Annona. Juristische Aspekte der stadtrömischen Lebensmittelversorgung im Prinzipat, Graz 1997. 
society based purely on "bread and circuses," 24 to quote Juvenal, has developed. This has almost completely obliterated individual solidarity between citizens and in doing so, has almost entirely replaced a central element of their identification with an intensely personal whole. Cicero was clear that such a policy would have serious consequences for the state as a whole in the long term, when he wrote:

(Cic., Sest. 103) Caius Gracchus brought forward a law respecting corn. It was a very pleasing proposal to the common people at Rome; for food was to be supplied to them in abundance without any trouble. The good resisted it because they thought that its effect would be to lead the common people away from industry to idleness, and because the treasury was likely to be drained by such a measure.

\subsection{Elite democracy}

Motivated by purely material interests and overburdened by the increasing complexity of state leadership, citizens stop wanting to be actively involved in politics, whether that is in contemporary democracy ${ }^{25}$ or in the res publica Romana. ${ }^{26}$ This attitude, which is fundamentally apolitical and only inclined towards public matters when specific and short-term electoral promises are on the line, not only results in political decision makers losing accountability, but also promotes the rise of a technocratic elite, which acts in the name of procedural logic and economic efficiency and whose formation is only legitimised by ideologically aligned major parties. Today, only a quarter of European citizens trust their government, parliament or the European Union, ${ }^{27}$ and the Republic in Rome also faced a serious crisis, as Sallust wrote in a letter to Caesar:

([Ps.]Sall., epist. 1.5.4-5) When, however, idleness and poverty gradually drove the commons from the fields and forced them to live without a fixed abode, they began to covet the riches of other men and to regard their liberty and their country as objects of traffic. Thus little by little the people, which had been sovereign and had exercised

${ }^{24}$ Iuv., Sat. 10.77-81.

${ }^{25}$ On the crisis of democracy in the West, cf. C. Crouch, Post-Democracy, Oxford 2004; S. Spindler, I. Tonks (eds), Ausnahmezustände. Krise und Zukunft der Demokratie, Münster Duisburg 2007; G. Steingart, Die gestohlene Demokratie. Das Wahlbuch '09, Zürich 2009; B. von Weizsäcker, Warum ich mich nicht für Politik interessiere, Munich 2009; H. Münkler, Lahme Dame Demokratie, in: Internationale Politik, May-June, 2010.

${ }^{26}$ On the crisis of political participation in the late-republican Rome, cf. C. Nicolet, Le Métier de citoyen dans la Rome républicaine, Paris 1979; M. Jehne (ed.), Demokratie in Rom?, Stuttgart 1996; A. Yakobson, Elections and Electioneering in Rome. A Study in the Political System of the Late Republic, Stuttgart 1999; H. Mouritsen, Plebs and Politics in the Late Roman Republic, Cambridge, MA, 2001; V. Fadinger, Der Staat als Beute der Parteien. Krise und Untergang der römischen Republik 133-30 v. Chr., vol. 1, Vorgeschichte und Beginn der Krise von ca. 200 v. Chr. bis zum Tod des C. Marius 86 v. Chr., Berlin 2000.

${ }^{27}$ In late 2016, only 33\% of those consulted trusted in the European Union, 28\% in their respective national parliament, $27 \%$ in their respective national government (Eurobarometr 85 ). 
authority over all nations, became degenerate, and each man bartered his share of the common sovereignty for slavery to one man. 1.10.8-11.1: To-day, on the contrary, certain of the nobles, whose minds are possessed by indolence and cowardice, although they are ignorant of hardship, of the enemy, and of military life, have formed a faction within the state and arrogantly claim sovereignty over all nations. Thus the Fathers, by whose wisdom the wavering state was formerly steadied, are overpowered and tossed to and fro according to the caprice of others; they decree now one measure and now another, determining what is helpful or harmful to the public from the enmity or favour of their masters.

\subsection{Populism}

Resistance against numerous internal problems, as well as frustration with the increasingly out-of-touch political elite, is sparking a rise of so-called “populist” parties in Western Europe ${ }^{28}$ just as it produced “popular” politicians in late-republican Rome. ${ }^{29}$ These parties and politicians base themselves on an often fitting assessment of the present situation, but they are not usually able to develop or enforce convincing alternative models, especially as the close alliance of the established elite robs them of any opportunity to actually implement their proposals. Their legitimate criticism therefore does not contribute to reconstruction, but rather to disintegration, and these movements often degenerate into pure demagoguery, as we see, for example, in the astonishingly relevant Catiline Orations recorded by Sallust:

(Sall., Cat. 20.7-9) For ever since the state fell under the jurisdiction and sway of a few powerful men, it is always to them that kings and potentates are tributary and peoples and nations pay taxes. All the rest of us, energetic, able, nobles and commons, have made up the mob, without influence, without weight, and subservient to those to whom in a free state we should be an object of fear. Because of this, all influence, power, rank, and wealth are in their hands, or wherever they wish them to be; to us they have left danger, defeat, prosecutions, and poverty. How long, pray, will you endure this, brave hearts?

${ }^{28}$ On populism in the West, cf. S. Frölich-Steffen, L. Rensmann (eds), Populisten an der Macht - Populistische Regierungsparteien in West- und Osteuropa, Vienna 2005; R. Faber, F. Unger, Populismus in Geschichte und Gegenwart, Würzburg 2008; Y. Mény, Y. Surel (eds), Democracies and the Populist Challenge, Basingstoke 2014; J. Abromeit et al. (eds), Transformations of Populism in Europe and the Americas: History and Recent Tendencies, London 2015; B. Moffitt, The Global Rise of Populism: Performance, Political Style, and Representation, Stanford 2016; W. Brömmel et al., Populismus und Extremismus in Europa. Gesellschaftswissenschaftliche und sozialpsychologische Perspektiven, Bielefeld 2017.

${ }^{29}$ On populism in the late-republican Antiquity, cf. J. Martin, Die Popularen in der Geschichte der späten römischen Republik, Freiburg i. Br. 1965; J. Bleicken, Staatliche Ordnung und Freiheit in der römischen Republik, Kallmünz 1972; C. Meier, Res publica amissa. Eine Studie zu Verfassung und Geschichte der späten römischen Republik, Wiesbaden 1980; H. Brenner, Die Politik des P. Clodius Pulcher; Untersuchungen zur Denaturierung des Clientelwesens in der ausgehenden römischen Republik, Wiesbaden 1987; C. Döbler, Politische Agitation und Öffentlichkeit in der späten Republik, Frankfurt a.M. 1999. 


\subsection{The call for order}

Political polarisation among citizens quickly causes the system to overheat. As a result, this system is rapidly losing its credibility in the West $^{30}$, just as it did in ancient times. ${ }^{31}$ As political fronts largely solidify and open debates are virtually frozen, citizens not only lose trust in their institutions, but also in the value of their own freedoms, and they are increasingly prepared to consider radical solutions to upset the unbearable status quo. Today, two thirds of Europeans are prepared to sacrifice their personal freedoms in order to achieve greater equality and justice. ${ }^{32}$ This sentiment is echoed in the following description by Appian addressing the reasons why the Romans were so willing to dedicate themselves to a dictator:

(App., Civ. 2.19-20) The magistrates were chosen by means of money, and faction fights, with dishonest zeal, with the aid of stones and even swords. Bribery and corruption prevailed in the most scandalous manner. The people themselves went already bought to the elections. [...] For these reasons good men abstained from office altogether, and the disorder was such that at one time the republic was without consuls for eight months, Pompey conniving at the state of affairs in order that there might be need of a dictator. Many citizens began to talk to each other about this, saying that the only remedy for existing evils was the authority of a single ruler, but that there was need of a man who combined strength of character and mildness of temper, thereby indicating Pompey [...]. The expectation of a dictatorship Pompey discountenanced in words, but in fact he did everything secretly to promote it, and went out of his way to overlook the prevailing disorder and the anarchy consequent upon the disorder.

\section{Prospects}

With regard to all the threats of crisis in the Roman Republic and modern European society, a quote has rarely been so pertinent as this from Cicero's “de re publica”: "Due to our mistakes, not just some misfortune, we have a firm grasp on the commonwealth in words alone; in reality, it has long been lost.” (Cic., rep. 5.1). In view of the extent and severity of the analogies outlined briefly here, it is now the duty of historians to address the inevitable consequences of this situation. Since all

${ }^{30}$ On law and order in the West, cf. R. Dulong, H.-P. Jeudy, Imaginaire de l'insécurité, Paris 1983; S. Roché, Le Sentiment d'insécurité, Paris 1993; B. Buzan et al., Security. A New Framework for Analysis, Boulder, CO, 1998; S. Croft, T. Terriff (eds), Critical Reflections on Security and Change, London 2000; S. Roché, Sociologie politique de l'insécurité, Paris 2004; L. Bonelli, La France a peur. Une histoire sociale de l'insécurité, Paris 2008.

${ }^{31}$ On law and order in late-republican Antiquity, cf. W. Nippel, Public Order in Ancient Rome, Cambridge, MA, 1995; A. Riggsby, Crime and Community in Ciceronian Rome, Austi 1999; J. Harries, Law and Crime in the Roman World, Cambridge, MA, 2007; C. Brélaz, P. Ducrey (eds), Sécurite collective et ordre public dans les sociétés anciennes, Geneva 2008.

${ }^{32}$ Source: Eurobarometer 69, spring 2008 (http://ec.europa.eu/public_opinion/archives/eb/ eb69/eb69_values_fr.pdf). 
the fundamental prerequisites for the European civilisation crisis seem to mirror those for the Roman one, it can be said with some certainty that the subsequent consequences will be comparable.

For the foreseeable future, the decline of contemporary society will not be followed by a period of gradual recovery, but rather, as in Rome in the first century $\mathrm{BC}$, there will be a prolonged period of serious unrest resembling a civil war. ${ }^{33}$ During this time, in Western Europe at least, we have to expect an increasing number of clashes between radicalised fundamentalist groups with various political and religious leanings, involving a complex overlapping of the fault lines between social (poor versus rich), ethnic (Christian versus Muslim), and finally ideological aspects (liberal versus conservative).

The extent and exact progression of the crisis will, of course, vary from state to state and from situation to situation, and it would be presumptuous to make any predictions about this. Nonetheless, it can generally be assumed that the combination of terrorism, mass impoverishment, de-industrialisation, state failure, the pressure on the legal system, poor education, mass immigration, demographic decline, public debt, infrastructure crises, low-wage solutions and financial speculation, together with the predictable collapse of the social and pension system and the overzealous worlds of finance and speculation, will eventually reach boiling point. Just like in the Late Roman Republic, from this point onwards, the system will start to gradually collapse and dissolve from within, bringing with it a trivialisation of violence and injustice in everyday life and a rise of new alternative models for political control.

Like in Rome, Europe is now witnessing a growing inability of the traditional political elite to resolve this, in many ways, self-inflicted crisis, which has been denied for years or even decades. This is because even admitting the true extent of the crisis equates to a confession of one's own failure, which would entail a complete abdication from the political stage. Furthermore, the current political institutions are fundamentally ill-equipped to cope with such a plethora of internal problems due of their complexity and the many layers of entanglement and mutual elimination of their institutions. This is particularly pertinent within the context of the current foreign policy situation with the collapse of Islamic nations, the new Cold War with Russia, the internal crisis in the USA, and the steadily growing competition from China as additional crisis factors.

33 Cf. in general D. Engels, Ceci n'est pas une crise, mais pourrait bien être le début de la fin, in: J.-P. Labille (ed.), Brexit! Le 'non’britannique décrypté, Paris 2016, pp. 57-67; D. Engels, The European Union and the Decline of the West, or: Determinism or Determination?, "Erträge" 5/2017, pp. 93-124; D. Engels, Interview mit K. Baltaci, in: Österreichischer Integrationsfonds (ed.), "Parallelgesellschaften. Segregation und desintegrative Milieus (Schriftenreihe: Perspektiven. Integration” 6/2017, pp. 16-23; D. Engels, Europa in nicht allzu ferner Zeit. Eine Dystopie, in: R. Grätz (ed.), Kann Kultur Europa retten?, Berlin 2017 (Bundeszentrale für politische Bildung), pp. 29-40. 
The unavoidable consequence of this will be that due to the strain on the state, it will soon only be able to control the strategically more important hubs, production areas, settlement zones and traffic connections using emergency laws, large-scale military and police operations, and with a hardening of the prevailing ideology. Whole districts and zones will, however, in effect be able to evade efficient state control in the long term and these areas will fall into the hands of paramilitary neighbourhood protection groups or fundamentalist religious groups that will take law and order into their own hands. This will entail all the associated problems, such as street fighting, corruption, crime, cleansing and production decline. This series of events, which is already looming, will initially be concealed or glossed over by the wider media. In the long term, however, it will not take long for citizens to compare their personal experiences and come to understand the full extent of the decline along with all the ensuing political consequences.

It cannot be assumed that the vicious circle of decline, poverty, unrest, state powerlessness, vigilante justice and moral brutalisation would only affect the economically weak, southern periphery of the continent. In fact, it would primarily impinge on its current gravitational centre, i.e. France, Germany, the Benelux countries and the United Kingdom. The greatest impact would be felt in urban areas that are already worst affected by poverty and migration, such as Paris, Marseille, Brussels, London, the old northern English industrial areas, the Ruhr area and Berlin. This would cause an even greater strain because, on the one hand, these metropolitan regions greatly depend on external supply, and on the other, the countries concerned are completely economically invested in export or highly complex services in the tertiary sector, and are therefore particularly susceptible to any kind of disruption to their internal equilibrium. Furthermore, these regions are firmly in the hands of the "politically correct" media and political landscape, which will prevent any real insight into the severity of the crisis for as long as possible. They are also affected by such a high level of demographic decline and ethnic-cultural change that the class and political struggle could easily tip over into a war of civilisation. At best, it is possible that the Visegrad countries would be largely excluded from this emerging set of circumstances, although they would still be greatly affected by the inevitable collateral damage of sustained decline in Western Europe. It is not impossible that after the transformation phase, these countries could emerge as the new centre of the continent's regeneration.

\section{Outlook}

It would be too presumptuous at this stage to consider what this regeneration might look like, but a continuation of the comparison with Rome and the outcome of the Roman civil wars could provide a helpful model. 
It is well known that the downfall of the Republic during the civil wars was followed by its fundamental reform carried out by Augustus, founder of the Principate and guarantor of the worldwide Pax Augusta, which laid the foundations for peace, prosperity and order in the Mediterranean over the next half a millennium. ${ }^{34}$ The assessment of this central figure in Roman history is still highly contentious, but it is hardly surprising that the lasting damage left by the Roman civil war, which was institutional and psychological as well as material, could only be rectified, or at least limited, by a long-term forward-planning policy, which could only be enacted by transferring many of the formerly purely republican powers to the new sovereign.

At first, this may not seem like a particularly enticing prospect. In this context, however, we must question the extent to which the transition from the oligarchy and plutocracy of the Senate regime to the Principate of Augustus and his successors, which was regularly validated by a plebiscitary, truly entailed a loss of rights for ordinary citizens. As contemporary witnesses like Dionysius of Halicarnassus understood it, it actually resulted in an increase in collective democratic influence. ${ }^{35}$ Today's present form of democracy, which is ultimately a mixture of plutocracy and technocracy, is clearly an out-dated model for most young people, just as the late-republican senate regime had become more a matter of fear than nostalgia for most Romans. In many western countries, such as Sweden, Australia, the Netherlands, the USA, New Zealand and the UK, the number of people who believe it is "essential" to live in a democracy is significantly decreasing over time, ${ }^{36}$ and in France, 41\% of the population seem ready to accept an authoritarian state in order to push through the necessary reforms of the society. ${ }^{37}$ If Europe manages to reunite again after the anticipated period of crisis, it can be assumed that the demise of complex Brussels bureaucracy would hardly be regarded as a loss in the West, especially if a subsequent democratically elected European government stood firmly by the continent's cultural traditions and interests and did not insist on making itself the overseer of the world markets, globalisation, mass immigration and international institutions.

${ }^{34}$ General introduction: G. Binder (ed.), Saeculum Augustum, 3 Bde., Darmstadt 1987-1991; D.C.A. Shotter, Augustus Caesar, London 1991; J. Bleicken, Augustus. Eine Biographie, Berlin 1998; P. Southern, Augustus, London - New York, NY, 1998; K. Bringmann, Th. Schäfer, Augustus und die Begründung des römischen Kaisertums, Berlin 2002; D. Kienast, Augustus. Prinzeps und Monarch, Darmstadt 2009.

35 Dion. Hal. 4.21: "It was of great advantage to the Republic that the same citizens who deliberated on public affairs also exposed themselves more than others to outer perils, due to the necessity of executing with zeal what had been decided by the assemblies. This good order of government has been maintained for centuries by the Romans. But in our days [i.e. the Augustan period], it has been entirely reversed by an outer force, and urgent necessity has changed it into a more democratic government.”

${ }^{36}$ For people born in the 1980s, approval is only approximately $30 \%$ in all the countries listed (except Sweden). Cf.: https://www.journalofdemocracy.org/article/signs-deconsolidation.

37 Cf. https://www.nouvelobs.com/societe/20181031.OBS4775/41-des-francais-prets-a-unpouvoir-autoritaire-pour-reformer-le-pays-en-profondeur.html 
Of course, this is where the possibilities of historical predictions fall short, as the precise nature of the framework of the European state which results from the feared crisis will largely depend on the way the crisis progresses, which we can only vaguely predict. This prospect of a stabilised society across Europe, like that of the Augustan Principate, with a conservative return to the basic values of European tradition could be seen as an optimistic conclusion to my presentation. It at least provides some hope that the expected phase of decline will not be followed by complete collapse - some form of revival will ensue.

Perhaps Tacitus also had this ambivalent attitude when, almost a century after the death of Augustus, he retrospectively made the following verdict on the first princeps:

(Tac., ann. 1.2-4) After laying down his triumviral title and proclaiming himself a simple consul content with tribunician authority to safeguard the commons, he first conciliated the army by gratuities, the populace by cheapened corn, the world by the amenities of peace, then step by step began to make his ascent and to unite in his own person the functions of the senate, the magistracy, and the legislature. Opposition there was none: the boldest spirits had succumbed on stricken fields or by proscription-lists; while the rest of the nobility found a cheerful acceptance of slavery the smoothest road to wealth and office, and, as they had thriven on revolution, stood now for the new order and safety in preference to the old order and adventure. Nor was the state of affairs unpopular in the provinces, where administration by the Senate and People had been discredited by the feuds of the magnates and the greed of the officials, against which there was but frail protection in a legal system for ever deranged by force, by favouritism, or (in the last resort) by gold. [...] The officials carried the old names; the younger men had been born after the victory of Actium; most even of the elder generation, during the civil wars; few indeed were left who had seen the Republic. It was thus an altered world, and of the old, unspoilt Roman character not a trace lingered. Equality was an outworn creed, and all eyes looked to the mandate of the sovereign.

\section{Literature}

Abromeit J. et al. (eds), Transformations of Populism in Europe and the Americas: History and Recent Tendencies, London 2015.

Albert S., Bellum iustum. Die Theorie des gerechten Krieges und ihre praktische Bedeutung für die auswärtigen Auseinandersetzungen Roms in republikanischer Zeit, Kallmünz 1980 .

Altizer Th.J.J., Hamilton W., Radical Theology and the Death of God, Indianapolis 1966.

Bade K., Europa in Bewegung. Migration vom späten 18. Jahrhundert bis zur Gegenwart, Munich 2000.

Baltes P.B., Mittelstraß J. (eds), Zukunft des Alterns und gesellschaftliche Entwicklung, Berlin - New York, NY 1992.

Barber B.R., Consumed. How Markets Corrupt Children, Infantilize Adults, and Swallow Citizens Whole, New York, NY, 2008. 
Baudrillard J., La Société de consommation, Paris 1970.

Bellancourt-Valdher M., Corvisier J.-N., La Démographie historique antique, Arras 1999. Beloch K.J., Die Bevölkerung der griechisch-römischen Welt, Leipzig 1886.

Berchem D. van, Les distributions de blé et d'argent à la plèbe romaine sous l'Empire, Genève 1932.

Berghoff H., Spiekermann U. (eds), Decoding Modern Consumer Societies, New York, NY, 2012.

Bhagwati J., In Defense of Globalization, Oxford 2004.

Binder G. (ed.), Saeculum Augustum, 3 Bde., Darmstadt 1987-1991.

Blamires H., The Post Christian Mind: Exposing its Destructive Agenda, Vine 1999.

Blätter für deutsche und internationale Politik (ed.), Der Sound des Sachzwangs - Der Globalisierungs-Reader. With 30 contributions from Elmar Altvater, Samir Amin, Peter Bender, Noam Chomsky, Mike Davis, Erhard Eppler, Johan Galtung, Jürgen Habermas, Samuel P. Huntington, Naomi Klein, Birgit Mahnkopf, Peter Marcuse, Saskia Sassen et al., Bonn - Berlin 2006; B. Rehbein, H. Schwengel, Theorien der Globalisierung, Konstanz 2008.

Bleicken J., Augustus. Eine Biographie, Berlin 1998.

Bleicken J., Staatliche Ordnung und Freiheit in der römischen Republik, Kallmünz 1972.

Boeri T., Brücker H., Why are Europeans so Tough on Migrants?, "Economic Policy” 44, October 2005.

Bonelli L., La France a peur. Une histoire sociale de l'insécurité, Paris 2008.

Boucher et al. F.-E. (eds), La Paix. Esthétiques d'une éthique, Bern et al. 2007.

Brandt H., Panhellenismus, Partikularismus und Xenophobie. Fremde in griechischen Poleis der klassischen Zeit, “Eos” 80/1992, pp. 191-202.

Brasseul J., Un monde meilleur? Pour une autre approche de la mondialisation, Paris 2005.

Brélaz C., Ducrey P. (eds), Sécurite collective et ordre public dans les sociétés anciennes, Geneva 2008.

Brenner H., Die Politik des P. Clodius Pulcher; Untersuchungen zur Denaturierung des Clientelwesens in der ausgehenden römischen Republik, Wiesbaden 1987.

Bringmann K., Schäfer Th., Augustus und die Begründung des römischen Kaisertums, Berlin 2002.

Brömmel W. et al., Populismus und Extremismus in Europa. Gesellschaftswissenschaftliche und sozialpsychologische Perspektiven, Bielefeld 2017.

Buzan B. et al., Security. A New Framework for Analysis, Boulder, CO, 1998.

Castles S., Miller M., The Age of Migration. International Population Movements in the Modern World, London 2003.

Cohen D., La Mondialisation et ses ennemis, Paris 2004.

Corvisier J.-N., Suder W., Polyanthropia-oliganthropia. Bibliographie de la démographie du monde grec, Paris 1996.

Coşkun A., L. Raphael (eds), Fremd und rechtlos? Zugehörigkeitsrechte Fremder von der Antike bis zur Gegenwart. Ein Handbuch, Cologne - Weimar - Vienna 2014.

Cracco Ruggini L., Pregiudizi razziali, ostilità politica e culturale, intolleranza religiosa nell'impero romano, “Athenaeum” 46/1968.

Croft S., Terriff T. (eds), Critical Reflections on Security and Change, London 2000.

Crouch C., Post-Democracy, Oxford 2004.

David J., La Romanisation de l'Italie, Paris 1994. 
Döbler C., Politische Agitation und Öffentlichkeit in der späten Republik, Frankfurt a.M. 1999.

Dulong R., Jeudy H.-P., Imaginaire de l'insécurité, Paris 1983; S. Roché, Le Sentiment d'insécurité, Paris 1993.

Dupâquier J., Laulan Y.-M., Ces migrants qui changent la face de l'Europe, Paris 2004.

Engels D., Auf dem Weg ins Imperium? Die Krise der Europäischen Union und der Untergang der römischen Republik. Historische Parallelen, Berlin - Munich, 2014.

Engels D., Ceci n'est pas une crise, mais pourrait bien être le début de la fin, in: J.-P. Labille (ed.), Brexit! Le 'non’ britannique décrypté, Paris 2016.

Engels D., Europa in nicht allzu ferner Zeit. Eine Dystopie, in: R. Grätz (ed.), Kann Kultur Europa retten?, Berlin 2017.

Engels D., Interview mit K. Baltaci, in: Österreichischer Integrationsfonds (ed.), "Parallelgesellschaften. Segregation und desintegrative Milieus (Schriftenreihe: Perspektiven. Integration” 6/2017.

Engels D., L'étendue de la cité est un objet que l'homme politique ne doit pas négliger. Les critiques de la mégapole dans l'Antiquité méditerranéenne, “Latomus” 72/2013.

Engels D., Le Déclin. La crise de l'Union européenne et la chute de la république romaine - analogies historiques, Paris 2013.

Engels D., The European Union and the Decline of the West, or: Determinism or Determination?, "Erträge” 5/2017.

Faber R., Unger F., Populismus in Geschichte und Gegenwart, Würzburg 2008.

Fadinger V., Der Staat als Beute der Parteien. Krise und Untergang der römischen Republik 133-30 v. Chr., vol. 1, Vorgeschichte und Beginn der Krise von ca. 200 v. Chr. bis zum Tod des C. Marius 86 v. Chr., Berlin 2000.

Finley M., The Ancient Economy, Berkeley, CA, 1973.

Fontanel J., La Globalisation en »analyse« - Géoéconomie et stratégie des acteurs, Paris 2005.

Frölich-Steffen S., Rensmann L. (eds), Populisten an der Macht-Populistische Regierungsparteien in West- und Osteuropa, Vienna 2005.

'Futuromètre' from 2016, https://www.rtbf.be/info/societe/detail_futurometre-91-des-francophones-veulent-changer-de-systeme?id=9436297.

Garnsey P., Famine and Food Supply in the Graeco-Roman World. Response to Rise and Crisis, Cambridge, MA, 1988.

Geffcken J., Der Ausgang des griechisch-römischen Heidentums, Heidelberg 1920.

Geraghty R.M., The Impact of Globalization in the Roman Empire, 200 BC-AD 100, "Journal of Economic History" 67/2007.

Goody J., The Development of the Family and Marriage in Europe, Cambridge, MA, 1983.

Gruen E.S., Culture and National Identity in Republican Rome, Ithaca, NY, 1992.

Harries J., Law and Crime in the Roman World, Cambridge, MA, 2007.

Hatton T.J., Williamson J.G., The Age of Mass Migration, Oxford 1998.

Herz P., Studien zur römischen Wirtschaftsgesetzgebung. Die Lebensmittelversorgung, Stuttgart 1988.

Hingley R., Globalizing Roman Culture. Unity, Diversity and Empire, London 2005.

Hirsch A., Delhom P. (eds), Denkwege des Friedens. Aporien und Perspektiven, Freiburg i. Br. - Munich 2007. 
Höbenreich E., Annona. Juristische Aspekte der stadtrömischen Lebensmittelversorgung im Prinzipat, Graz 1997.

Humbert M., Le Remariage à Rome. Étude d'histoire juridique et sociale, Milan 1972.

Jehne M. (ed.), Demokratie in Rom?, Stuttgart 1996.

Jenkins Ph., God's Continent: Christianity, Islam and Europe's Religious Crisis, Oxford 2005.

Jenks St., Banken und Finanzkrisen, Lübeck 2012.

Joppke C., Morawska E. (eds), Toward Assimilation and Citizenship. Immigrants in Liberal Nation States, London 2003.

Kajanto I., On Divorce among the Common People of Rome, "REL" 47/1969.

Kaufmann F.-X., Schrumpfende Gesellschaft. Vom Bevölkerungsrückgang und seinen Folgen, Frankfurt a. M., 2005.

Kernig C.D., Und mehret euch? Deutschland und die Weltbevölkerung im 21. Jahrhundert, Bonn 2006.

Kertzer D.I., Barbagli M., The History of the European Family. Family Life in the Long Nineteenth Century (1789-1913), Yale, CT 2002.

Kienast D., Augustus. Prinzeps und Monarch, Darmstadt 2009.

Kleinert C., Fremdenfeindlichkeit: Einstellungen junger Deutscher zu Migranten, Opladen 2004, E. Oeser, Die Angst vor dem Fremden. Die Wurzeln der Xenophobie, Darmstadt 2015.

Klose H.-U. (ed.), Altern hat Zukunft - Bevölkerungsentwicklung und dynamische Wirtschaft, Opladen 1993.

König W., Geschichte der Konsumgesellschaft, Stuttgart 2000.

Kopp J., Geburtenentwicklung und Fertilitätsverhalten, Konstanz 2002.

Koppe K., Der vergessene Frieden. Friedensvorstellungen von der Antike bis zur Gegenwart, Opladen 2001.

Kotz D.M., The Rise and Fall of Neoliberal Capitalism, Cambridge, MA, 2015.

Landry A., Quelques aperçus concernant la dépopulation dans l'Antiquité gréco-romaine, "RH” 77/1935.

Latte K., Römische Religionsgeschichte, Munich 1960.

Levy E., Der Hergang der römischen Ehescheidung, Weimar 1925.

Lo Cascio E., Recruitment and the Size of the Roman Population from the Third to the First Century BCE, in: W. Scheidel (ed.), Debating Roman Demography, Leiden 2001.

Lüscher K., Schultheis F., Wehrspaun M., Die 'postmoderne'Familie-familiale Strategien und Familienpolitik in einer Übergangszeit, Konstanz 1988.

Mantovani M., Bellum iustum. Die Idee des gerechten Krieges in der römischen Kaiserzeit, Bern et al. 1990.

Martin J., Die Popularen in der Geschichte der späten römischen Republik, Freiburg i. Br. 1965.

Meier C., Res publica amissa. Eine Studie zu Verfassung und Geschichte der späten römischen Republik, Wiesbaden 1980.

Mény Y., Surel Y. (eds), Democracies and the Populist Challenge, Basingstoke 2014.

Modood T., Werbner P., The Politics of Multiculturalism. Racism, Identity and Community in the New Europe, London 1997.

Moffitt B., The Global Rise of Populism: Performance, Political Style, and Representation, Stanford 2016. 
Morley N., Theories, Models and Concepts in Ancient History, London 2004.

Mouritsen H., Plebs and Politics in the Late Roman Republic, Cambridge, MA, 2001.

Münkler H., Lahme Dame Demokratie, in: Internationale Politik, May-June, 2010.

Nardin T., The Ethics of War and Peace. Religious and Secular Perspectives, Princeton, NJ 1996.

Nicolet C., Le Métier de citoyen dans la Rome républicaine, Paris 1979.

Nippel W., Public Order in Ancient Rome, Cambridge, MA, 1995.

Otte M., Der Crash kommt: Die neue Weltwirtschaftskrise und wie Sie sich darauf vorbereiten, Berlin 2006.

Parkin T.G., Demography and Roman Society, London 1992.

Pitts M., Versluys M.J. (eds), Globalisation and the Roman World. World History, Connectivity and Material Culture, Cambridge 2015.

Rawson B. (ed.), Marriage, Divorce, and Children in Ancient Rome, Oxford 1991.

Rawson B. (ed.), The Family in Ancient Rome. New Perspectives, London 1986.

Rickman G., The Corn Supply of Ancient Rome, Oxford 1980.

Riggsby A., Crime and Community in Ciceronian Rome, Austi, 1999.

Ritzer G., The McDonaldization of Society, Thousand Oaks, CA, 1995.

Roché S., Sociologie politique de l'insécurité, Paris 2004.

Rostovtzeff M., Social and Economic History of the Roman Empire, Oxford 1926.

Rüpke J., Die Religion der Römer, Munich 2006; D. Engels, Das römische Vorzeichenwesen, Stuttgart 2007.

Salmon P., Population et dépopulation dans l'Empire Romain, Brussels 1974.

Scheid J., Religion et piété à Rome, Paris 2001.

Schmidt S., Markt ohne Moral - Das Versagen der internationalen Finanzelite, Munich 2010.

Sherwin-White A.N., Racial Prejudice in Imperial Rome, London 1967.

Shotter D.C.A., Augustus Caesar, London 1991.

Siegmund J., Bevölkerungsrückgang. Alterung und Technischer Fortschritt, Dresden 1993.

Southern P., Augustus, London - New York, NY, 1998.

Spindler S., Tonks I. (eds), Ausnahmezustände. Krise und Zukunft der Demokratie, Münster - Duisburg 2007.

Stangl G., Antike Populationen in Zahlen. Überprüfungsmöglichkeiten von demographischen Zahlenangaben in antiken Texten, Frankfurt a. M. 2008.

Steingart G., Die gestohlene Demokratie. Das Wahlbuch '09, Zürich 2009.

Suder W., Census Populi. Bibliographie de la démographie de l'Antiquité romaine, Bonn 1988.

Taylor Ch., A Secular Age, Harvard 2007.

Treggiari S., Roman Marriage. Iusti Coniuges from the Time of Cicero to the Time of Ulpian, Oxford 1991.

Turcan R., Religion romaine, Leiden 1988.

Vahanian G., The Death of God: The Culture of Our Post-Christian Era, New York 1961.

Waddy L., Pax romana and World Peace, New York 1950.

Weizsäcker B. von, Warum ich mich nicht für Politik interessiere, Munich 2009.

Wendt C., Sine Fine. Die römische Außenpolitik von der späten Republik bis in den frühen Prinzipat, Berlin, 2008. 
Wierschowskli L., Die historische Demographie - ein Schlüssel zur Geschichte?, "Klio“ 76/1994.

Wissowa G., Religion und Kultus der Römer, Munich 1912.

Yakobson A., Elections and Electioneering in Rome. A Study in the Political System of the Late Republic, Stuttgart 1999. 
